\title{
Targeting of preexisting and induced breast cancer stem cells with trastuzumab and trastuzumab emtansine (T-DM1)
}

\author{
J Diessner ${ }^{\star, 1}$, V Bruttel ${ }^{1}$, RG Stein ${ }^{1,2}$, E Horn ${ }^{1}$, SF M Häusler ${ }^{1,3}$, J Dietl ${ }^{1}$, A Hönig ${ }^{1,3}$ and J Wischhusen ${ }^{\star, 1,3}$
}

The antibody trastuzumab (Herceptin) has substantially improved overall survival for patients with aggressive HER2-positive breast cancer. However, about $70 \%$ of all treated patients will experience relapse or disease progression. This may be related to an insufficient targeting of the $\mathrm{CD} 44^{\text {high }} \mathrm{CD} 24^{\text {low }}$ breast cancer stem cell subset, which is not only highly resistant to chemotherapy and radiotherapy but also a poor target for trastuzumab due to low HER2 surface expression. Hence, we explored whether the new antibody-drug conjugate T-DM1, which consists of the potent chemotherapeutic DM1 coupled to trastuzumab, could improve the targeting of these tumor-initiating or metastasis-initiating cells. To this aim, primary HER2-overexpressing tumor cells as well as HER2-positive and HER2-negative breast cancer cell lines were treated with T-DM1, and effects on survival, colony formation, gene and protein expression as well as antibody internalization were assessed. This revealed that CD $44^{\text {high }}$ CD2 ${ }^{\text {low }}{ }^{\text {HER2 }}{ }^{\text {low }}$ stem cell-like breast cancer cells show high endocytic activity and are thus particularly sensitive towards the antibody-drug conjugate T-DM1. Consequently, preexisting CD44 ${ }^{\text {high }}$ CD24 ${ }^{\text {low }}$ cancer stem cells were depleted by concentrations of T-DM1 that did not affect the bulk of the tumor cells. Likewise, colony formation was efficiently suppressed. Moreover, when tumor cells were cocultured with natural killer cells, antibody-dependent cell-mediated cytotoxicity was enhanced, and EMT-mediated induction of stem cell-like properties was prevented in differentiated tumor cells. Thus our study reveals an unanticipated targeting of stem cell-like breast cancer cells by T-DM1 that may contribute to the clinical efficacy of this recently approved antibody-drug conjugate.

Cell Death and Disease (2014) 5, e1149; doi:10.1038/cddis.2014.115; published online 27 March 2014

Subject Category: Cancer

The Her-2/neu (c-erbB2, HER2) proto-oncogene is a transmembrane receptor tyrosine kinase ${ }^{1}$ that mediates critical cellular functions like growth, differentiation and survival in malignant and normal breast epithelial cells. Homodimerization of HER2 as well as heterodimerization of HER2 with the related receptors HER1/EGFR1/ErbB1, HER3 or HER4 triggers oncogenic signaling. ${ }^{2,3}$ Overexpression of the HER2 gene is associated with an aggressive clinical phenotype, increased disease recurrence and unfavorable prognosis. ${ }^{4}$ Although $20-30 \%$ of breast cancers show HER2 amplification, genome-wide sequencing has revealed activating HER2 mutations as an alternative mechanism for HER2 activation in breast cancer. ${ }^{5}$ Moreover, cancer stem cell (CSCs) were found to overexpress HER2 even in breast cancers not classified as HER2-positive. ${ }^{6}$ Thus HER2-directed treatments could be beneficial for numerous patients.

The humanized monoclonal antibody trastuzumab (Herceptin, Genentech), which binds to the extracellular domain of HER2, was found to reverse many oncogenic effects caused by the overexpression of HER2. In patients with HER2-positive breast and gastric cancer, trastuzumab could thus significantly improve disease-free and overall survival in the adjuvant and metastasized setting. ${ }^{7-9}$ Used as monotherapy, trastuzumab inhibits tumor cell growth. In combination with chemotherapeutics or ionizing radiation, duration of response and progression-free survival are improved. ${ }^{10,11}$

Mechanistically, trastuzumab does not block only signal transduction via the HER2 receptor and its interaction partners. By binding to HER2-overexpressing target cells, trastuzumab also 'labels' tumor cells for recognition by immune effectors like natural killer (NK) cells. These bind antibodies via Fc $\gamma$-receptors, which then trigger the so-called 'antibody-dependent cell-mediated cytotoxicity' (ADCC). ${ }^{12,13}$ The functional relevance of NK cell recruitment for the activity of trastuzumab is supported by a clinical correlation between NK cell function and therapeutic response, ${ }^{12}$ by a loss of activity in Fc $\gamma$-RIIIA knockout animals mice ${ }^{14}$ and by an improved in vivo effect of trastuzumab upon additional NK cell stimulation. ${ }^{15}$ Importantly, the Fc $\gamma$-part of trastuzumab, which mediates these immune-stimulatory effects, was retained in trastuzumab emtansine (T-DM1).

\footnotetext{
${ }^{1}$ Department for Obstetrics and Gynecology, University of Würzburg Medical School, Josef-Schneider-Street 4, Würzburg 97080, Germany; ${ }^{2}$ Else-Kröner Research Training Program for Clinician Scientists, University of Würzburg Medical School, Josef-Schneider-Street 4, Würzburg 97080, Germany and ${ }^{3}$ Interdisciplinary Center for Clinical Research (IZKF), University of Würzburg Medical School, Josef-Schneider-Street 4, Würzburg 97080, Germany

${ }^{*}$ Corresponding author: J Diessner or J Wischhusen, Department for Obstetrics and Gynecology, University of Würzburg Medical School, Josef-Schneider-Street 4, Würzburg 97080, Germany. Tel: +49 0931201 25253; Fax: +49 0931201 25406; E-mail: diessner-bw@ t-online.de or Wischhusen_J@ukw.de

Keywords: targeted therapy; HER2; T-DM1; tumor stem cells; breast cancer

Abbreviations: ADCC, antibody-dependent cell-mediated cytotoxicity; ALDH, aldehyde dehydrogenase 1; CFSE, carboxyfluorescein diacetate succinimidyl ester; CSC, cancer stem cell; EMT, epithelial-to-mesenchymal transition; NK, natural killer; T-DM1, trastuzumab emtansine

Received 17.6.13; revised 24.1.14; accepted 20.2.14; Edited by Y Shi
} 
In preliminary studies, we have already demonstrated the induction of NK cell-mediated ADCC by trastuzumab in vitro. Moreover, we could provide in vivo evidence that HER2positive cells surviving an ADCC challenge with NK cells and trastuzumab preferentially show a 'CSC-like' phenotype. ${ }^{16}$ CSCs or tumor-initiating or metastasis-initiating cells are, in breast cancer, characterized by a CD $44^{\text {high }} \mathrm{CD} 24^{\text {low }}$ phenotype, expression of ganglioside GD2, aldehyde dehydrogenase 1 (ALDH), high clonogenicity, high tumorigenicity and increased metastatic potential. ${ }^{17-19}$ Current concepts suggest that CSCs often resist cytotoxic treatments and are therefore responsible for recurrence. ${ }^{20,21}$ Moreover, recent data indicate that stress stimuli, ${ }^{22}$ unsuccessful treatments ${ }^{23}$ and inflammation ${ }^{24-26}$ can trigger the conversion of (partly) differentiated cancer cells towards a CSC-like phenotype. The underlying process that is known as 'epithelial-to-mesenchymal transition' (EMT) enables transformation of epithelial into highly mobile mesenchymal cells, which is required for embryonic development. In cancer, however, highly mobile cells that have lost their epithelial phenotype may cause metastasis.

A promising new tool for the treatment of HER2-positive breast cancer is the antibody-drug conjugate T-DM1. It consists of the antibody trastuzumab and the potent Maytansine-derivative DM1, which inhibits cell division and induces cell death ${ }^{27}$ by blocking the spindle apparatus. ${ }^{28,29}$ Due to its high toxicity as free drug and low activity at tolerated levels, Maytansine requires a specific targeting to become applicable for antitumor therapy. ${ }^{30-33}$ DM1 was thus chemically linked to trastuzumab with a drug-to-antibody ratio of $3.5: 1 .^{31}$ HER2 represents an excellent target for an antibody-drug conjugate as it is highly overexpressed on HER2-positive cancer cells ${ }^{34}$ and also found on CSCs in tumors that do not show general positivity for HER2. ${ }^{6}$ After binding to HER2, T-DM1 is internalized by endocytosis and degraded in lysosomes, causing the release of the active metabolite DM1. ${ }^{35}$

Importantly, the mechanisms of action of trastuzumab (such as ADCC and the blockade of HER2-specific signaling) are preserved in the T-DM1 conjugate, but the targeted delivery of a highly toxic chemotherapeutic to HER2-positive tumor cells provides an additional benefit that has already yielded impressive clinical results in the first studies. ${ }^{36}$ In this set of experiments, we now investigated whether the new HER2-specific antibody-drug conjugate T-DM1 could also improve the targeting of CSCs.

\section{Results}

T-DM1 induces dose- and time-dependent cell death in HER2-positive tumor cells. To quantify the surface expression of HER2, six breast cancer cell lines (BT-474, SK-BR-3, MCF-7, MDA-MB-231, HCC1806 and HCC1937) were either enzymatically detached with Accutase or mechanically scraped before being stained with trastuzumab followed by a Cy5-conjugated detection antibody. Irrespective of the mode of harvesting, quantification by flow cytometry (Figure 1a) confirmed high levels of HER2 on BT474 and SK-BR-3 cells (commonly classified as HER2 $2^{+++}$) and revealed significant HER2 surface expression on MCF-7 and MDA-MB-231 cells, whereas HCC1806 and HCC1937 cells were negative for HER2. Considering that the common description of MCF-7 and MDA-MB-231 as $\mathrm{HER} 2^{\mathrm{O}+37}$ is based on analysis by immunohistochemistry (compare Table 1), we presume that flow cytometric analysis is more sensitive. In fact, several previous studies could also show that HER2 represents a possible target in MCF-7 cells. ${ }^{6,38}$

Next, the sensitivity of HER2 ${ }^{\text {high }}$ (SK-BR-3 and BT474), HER2 ${ }^{+}$(MCF-7 and MDA-MB-231) and HER2 ${ }^{-}$(HCC1806 and HCC1937) breast cancer cell lines towards T-DM1 was tested over $96 \mathrm{~h}$. Light microscopy showed that dead cells round off and detach. Cell density could thus be determined by crystal violet staining and used as a surrogate parameter for cell death (Figure 1b). Data were confirmed by the metabolic WST-1 assay (not shown). Finally, the effect of HER2-specific therapeutics on breast cancer cells was assessed by cell cycle analysis. After staining of the cellular DNA with propidium iodide, cell cycle arrest is typically indicated by an increase of cells in $\mathrm{G}_{0} / \mathrm{G}_{1}$ or $\mathrm{G} 2 / \mathrm{M}$-phase, and cell death is evidenced by the appearance of a sub- $\mathrm{G}_{0}$ fraction (Figure 1c). In all three assays, T-DM1 dose-dependently induced cell death in HER2-expressing breast cancer cells but not in the HER2-negative triple-negative breast cancer cell lines HCC1806 and HCC1937. Likewise, we could not detect any significant effect of T-DM1 on primary lymphocytes, which are HER2-negative (data not shown). This confirmed that cytotoxic effects of T-DM1 are HER2 dependent. Trastuzumab, in contrast, had hardly any influence on cell cycle distribution or cell density in our assays (Figure 1c and data not shown).

\section{T-DM1 efficiently suppresses clonogenicity of breast cancer cells, even though HER2 surface expression is low on the $\mathrm{CD}_{4} 4^{\text {high }} \mathrm{CD} 24^{\text {low }} \mathrm{CSC}$ subset. Rather than acute cytotoxicity, colony formation is often a better in vitro test for the efficacy of anti-cancer drugs. ${ }^{39}$ Following $48 \mathrm{~h}$ of incubation with T-DM1, HER2-positive breast cancer cell lines like SK-BR-3 and BT-474 dose-dependently lost their clonogenic potential (Figure 2a), which suggests a selective depletion of clonogenic cells and thus a}

\footnotetext{
Figure 1 T-DM1 is toxic for HER2-positive tumor cells. (a) HER2 expression levels on MCF-7, MDA-MB-231, BT-474, SK-BR-3, HCC1937 and HCC1806 cells were assessed by flow cytometry using trastuzumab followed by a Cy5-conjugated anti-human detection antibody. Specific fluorescence intensities (SFIs) were calculated by dividing the median fluorescence obtained with the HER2-specific antibody by the mean fluorescence obtained with an equally labeled isotype control antibody of irrelevant specificity. Black curve: isotype control antibody $(10 \mu \mathrm{g} / \mathrm{ml})$, red curve: HER2 expression. (b) A total of $1 \times 10^{5}$ breast cancer cells per well were seeded in a 96 -well plate and treated with the indicated concentrations of T-DM1. After $96 \mathrm{~h}$, cell density was determined by crystal violet staining. All measurements were performed in triplicates. (c) Breast cancer cells were either left untreated (left panel) or treated with $10 \mu \mathrm{g} / \mathrm{ml}$ trastuzumab (middle) or $10 \mu \mathrm{g} / \mathrm{ml} \mathrm{T-DM1} \mathrm{(right} \mathrm{panel)} \mathrm{for} 48 \mathrm{~h}$. Cell cycle distribution was then assessed via DNA staining with propidium iodide followed by FACS analysis. The region representing the sub $G_{0}$ phase, that is, dead cells, is shaded in red, the $G_{0} / G_{1}$ peak is marked in green and the $G_{2} / M$ phase in blue. Representative experiments are shown ( $n \geq 3$ for all experiments)
} 


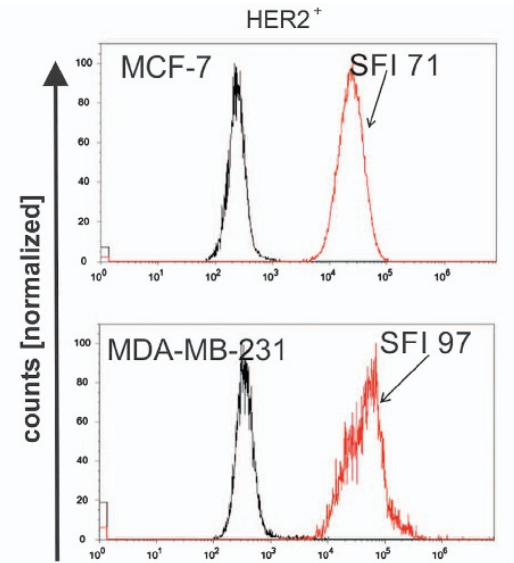

HER2 $^{\text {++ }}$

HER2
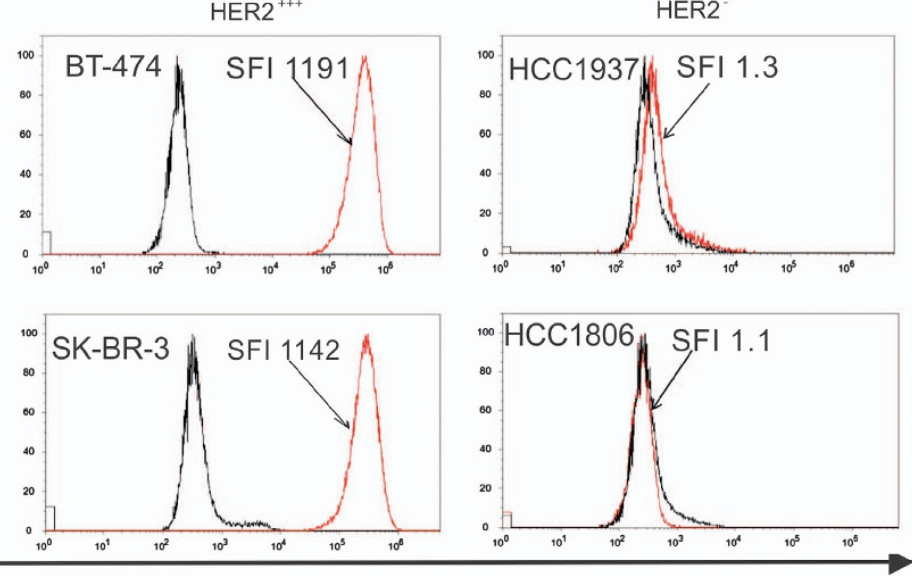

HER2-Cy5

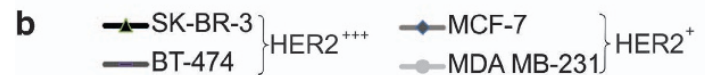

C

control

trastuzumab

T-DM1
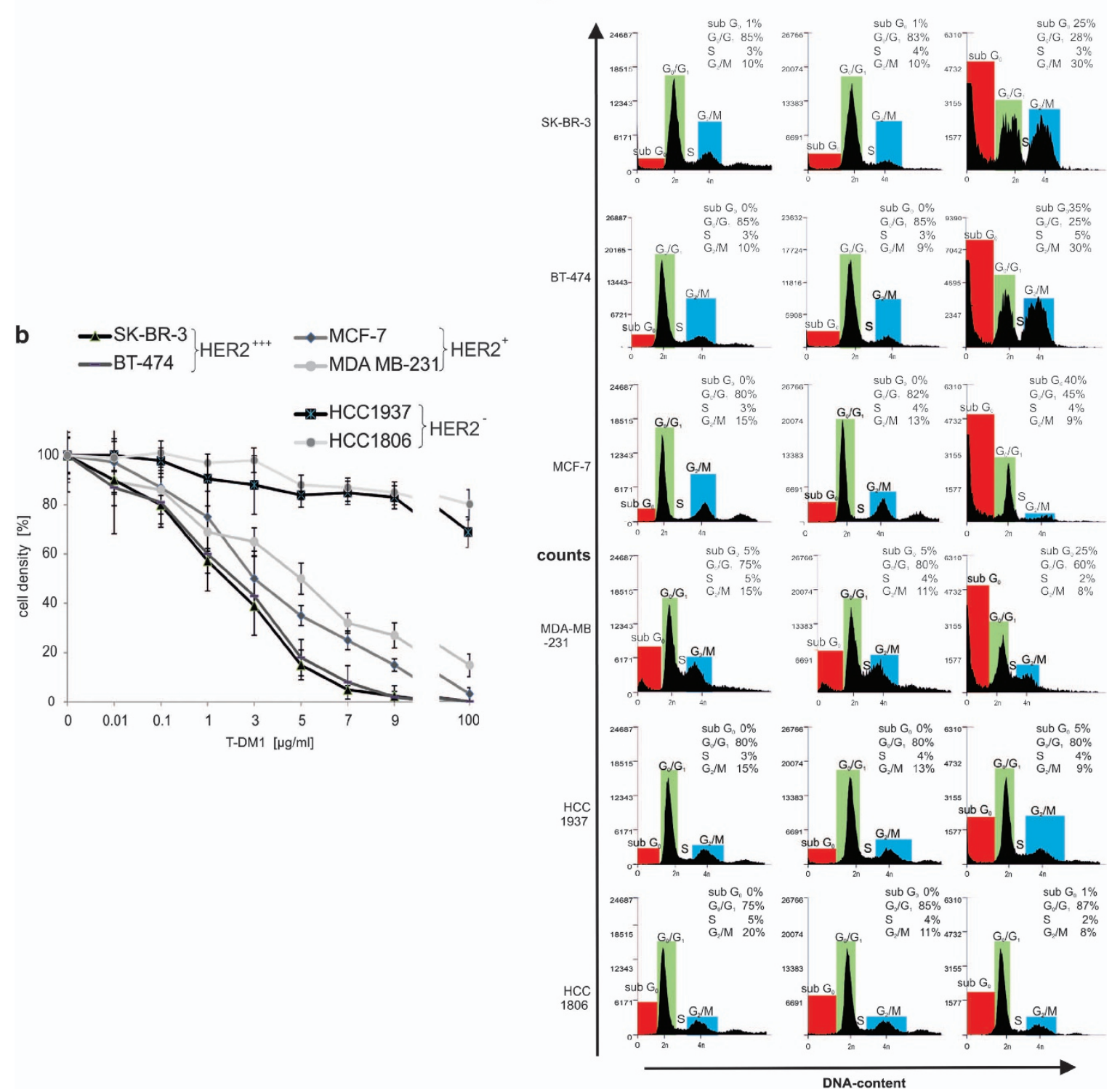
Table 1 Characteristics of breast cancer cell lines and primary patient-derived breast cancer cell cultures

\begin{tabular}{|c|c|c|c|c|c|c|c|c|}
\hline & $\begin{array}{l}\text { Age of } \\
\text { patient }\end{array}$ & $\begin{array}{l}\text { Estrogen } \\
\text { rez. }\end{array}$ & $\begin{array}{l}\text { Progesterone } \\
\text { rez. }\end{array}$ & Origin of cells & Primary tumor & Ethnicity & $\begin{array}{c}\text { Specific } \\
\text { fluorescence } \\
\text { indices (SFI) of } \\
\text { HER2 }\end{array}$ & $\begin{array}{c}\text { Immuno } \\
\text { histochemical } \\
\text { index (ICH) }\end{array}$ \\
\hline MCF-7 & 69 & Positive & Positive & Pleural effusion & Invasive ductal carcinoma & Caucasian & 82 & $0-1+{ }^{37}$ \\
\hline SK-BR-3 & 43 & Negative & Negative & Pleural effusion & Invasive ductal carcinoma & Caucasian & 1142 & $3+37$ \\
\hline BT474 & 60 & Positive & Positive & Solid tumor & Invasive ductal carcinoma & Caucasian & 1191 & $3+{ }^{37}$ \\
\hline MDA-MB-231 & 51 & Negative & Negative & Pleural effusion & Invasive ductal carcinoma & Caucasian & 97 & $0-1+{ }^{37}$ \\
\hline HCC1937 & 23 & Negative & Negative & Pleural effusion & Invasive ductal carcinoma & Caucasian & 1.1 & \\
\hline HCC1806 & 60 & Negative & Negative & Solid tumor & Invasive ductal carcinoma & Caucasian & 1.3 & \\
\hline Pat. 1 & 55 & Negative & Negative & Pleural effusion & Invasive ductal carcinoma & Caucasian & & $3+$ \\
\hline Pat. 2 & 72 & Positive & Negative & Pleural effusion & Invasive ductal carcinoma & Caucasian & & $3+$ \\
\hline Pat. 3 & 68 & Positive & Negative & Pleural effusion & Invasive ductal carcinoma & Caucasian & & $3+$ \\
\hline Pat. 4 & 66 & Positive & Positive & Pleural effusion & Invasive ductal carcinoma & Caucasian & & $3+$ \\
\hline Pat. 5 & 76 & Positive & Positive & Pleural effusion & Invasive ductal carcinoma & Caucasian & & $3+$ \\
\hline
\end{tabular}

preferential targeting of $\mathrm{CSC}^{39}$ by T-DM1. Trastuzumab, in contrast, had no such effect.

To confirm this hypothesis, we used MCF-7 cells from which a highly aggressive and poorly immunogenic ${ }^{40}$ CD $44^{\text {high }}$ CD24 ${ }^{\text {low }}$ CSC-like subset ${ }^{16,17}$ can be purified. Treatment of either unsorted MCF-7 cells or of purified CD44 ${ }^{\text {high }} C D 24^{\text {low }}$ cells did not only show the higher clonogenicity of this subpopulation but also confirmed the strong effect of T-DM1 on the clonogenicity of HER2-positive breast cancer cells (Figure 2b, upper panel). Similar data were obtained with MDA-MB-231 cells (Figure 2b, lower panel). Trastuzumab, in contrast, did not inhibit clonogenicity. For BT-474 and SK-BR3 cells, flow cytometric or magnetic bead-based enrichment of the CD $44^{\text {high }} C D 24^{\text {low }}$ subpopulation failed that precluded their use in this assay.

As T-DM1 concentrations $\leq 100 \mathrm{ng} / \mathrm{ml}$ almost abrogated clonogenicity in SK-BR-3, BT-474 and MCF-7 cells, we compared $\mathrm{EC}_{50}$ values for clonogenicity and cytotoxicity for all 6 cell lines (Figure 2c). The striking differences between these values show that T-DM1 preferentially targets clonogenic cells rather than the bulk of the tumor cell population. Again, HER2 positivity was a prerequisite for a discernible effect of T-DM1.

Importantly, clonogenicity (which, depending on the cell line, ranged from $5 \%$ to $26 \%$ ) can be used as a surrogate marker for CSCs. Our own previous findings, however, had shown lower HER2 surface expression on the CD44 $4^{\text {high }}$ $\mathrm{CD} 24^{\text {low }}$ presumed stem cell-like subset than on their more differentiated counterparts. ${ }^{41}$ In line with this observation, stem cell-like CD44 ${ }^{\text {high }} \mathrm{CD} 24^{\text {low }} \mathrm{HER} 2^{\text {low }}$ cells escaped from targeting with trastuzumab and NK cells. ${ }^{16}$ The reduced HER2 surface expression on CD $44^{\text {high }}$ CD2 $44^{\text {low }}$ cells was also now confirmed with primary tumor cells obtained from pleural effusions of five patients with metastasized HER2-positive breast cancer (Figure 2d and data not shown).

Effect of T-DM1 in the presence of NK cells. The therapeutic effect of anti-HER2 antibody treatment was found to correlate with the recruitment of NK cells in to the tumor microenvironment ${ }^{12}$ and to depend on both innate and adaptive immunity. ${ }^{42}$ One important mechanism is ADCC, ${ }^{16}$ which we found to be similar for trastuzumab and T-DM1 (Figure 3a). However, recruitment of immune cells into a tumor and inflammation can also promote EMT, which leads to dedifferentiation of cancer cells towards a CSC-like phenotype. ${ }^{24-26}$ In fact, coculture of MCF-7 breast cancer cells with NK cells did not induce morphological changes toward an elongated fibroblast-like shape, ${ }^{43,44}$ thereby indicating the transition from an epithelial to a mesenchymal phenotype (Figure 3b). Cell surface expression of the epithelial adherence factor E-Cadherin also decreased (Figure 3c). Western blotting revealed the induction of $\beta$-Catenin, Vimentin and (non-junctional) Claudin- $1^{45}$ (Figure 3d), which have been described during EMT. The characteristic transcription factors for EMT, Twist, Snail and Slug could, unfortunately, not be visualized by immunoblotting that may be due to their low and transient expression in MCF-7 cells. However, qRT-PCR analysis showed an induction of these factors on mRNA level that could be prevented by T-DM1 (Figure 3e). Accordingly, immunemediated induction of EMT could be prevented by T-DM1.

Effect of T-DM1 on induced breast CSCs. When T cells ${ }^{26}$ or NK cells ${ }^{16}$ induce EMT in breast cancer cells, induction of CSC-like properties can be the unwanted consequence. In line with these findings, coculture with NK cells increased the proportion of $\mathrm{CD} 44^{\text {high }} \mathrm{CD} 24^{\text {low }}$ cells in the MCF-7 cell line (Figure 4a). As an additional control, use of the ALDEFLUOR reagent system ${ }^{19}$ confirmed both stem cell induction in coculture with NK cells and the prevention of this effect by T-DM1 (Figure 4b). The enrichment of cells with a CSC signature was reflected by enhanced clonogenicity (Figure 4c). Both these effects could, again, be prevented by addition of T-DM1 to the cocultures, whereas trastuzumab showed no such effect (Figures $4 \mathrm{a}-\mathrm{c}$ and data not shown). Similar data were also obtained in other cell lines (shown for SK-BR-3 in Figures 4d and e). Accordingly, T-DM1 seems to be able to block the immune-mediated induction of tumor stem cells.

Maintenance of the $\mathrm{CD} 44^{\text {high }} \mathrm{CD} 24^{\text {low }}$ breast CSC phenotype requires autophagy. Our data show that the HER2-specific antibody-drug conjugate T-DM1 exerts strong effects on preexisting (Figure $2 \mathrm{~b}$ ) and induced (Figure 4a) CD44 ${ }^{\text {high }} \mathrm{CD} 24^{\text {low }}$ breast cancer CSCs, even though HER2 surface levels are low on this target cell population (Figure 2d). This apparent contradiction might be resolved by considering the high level of autophagy exerted by these cells. In fact, 

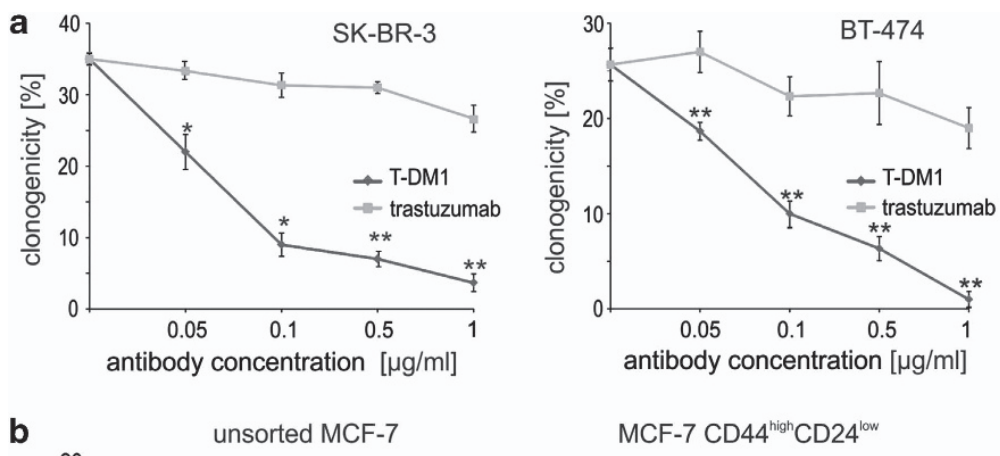

MCF-7 CD44 ${ }^{\text {high }} C D 24^{\text {low }}$
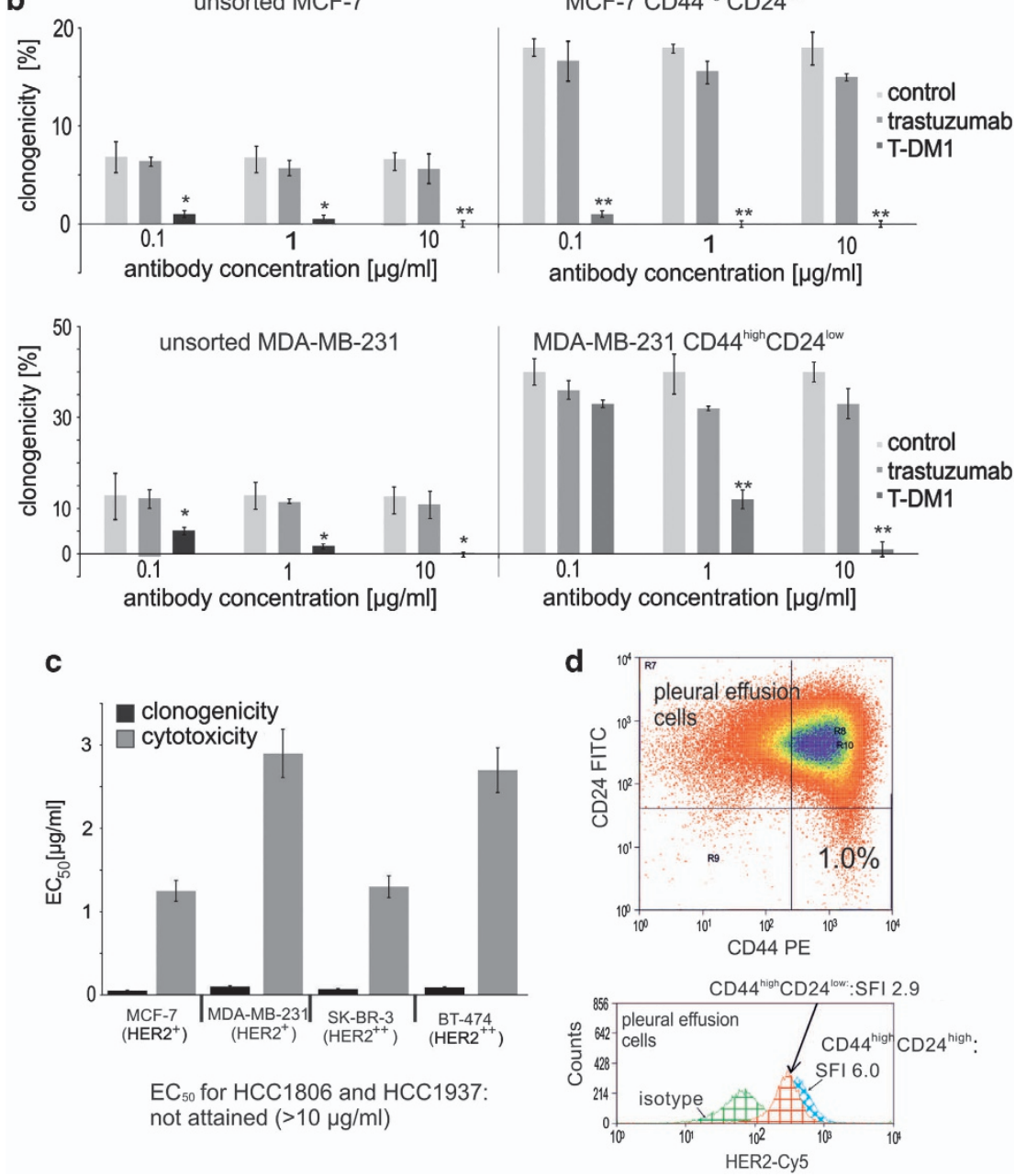

Figure 2 Preferential targeting of clonogenic breast cancer cells by T-DM1. (a) HER2-positive breast cancer cells (left: SK-BR-3, right: BT-474) were treated for 48 $\mathrm{h}$ with different concentrations of trastuzumab and T-DM1. Afterwards, clonogenicity of surviving tumor cells was analyzed by plating 100 and 500 viable cells. Three weeks later, colonies were first visualized by staining with crystal violet and then counted. The clonogenicity index corresponds to the percentage of cells that showed the ability to form new colonies. (b) CD44 ${ }^{\text {high }}$ CD24 ${ }^{\text {low }}$ breast cancer stem cells were isolated from the MCF-7 (upper panel) or MDA-MB-231 (lower panel) cell lines via FACS sorting. Subsequently, the clonogenicity of the unsorted and of the sorted cells was analyzed in the presence of different concentrations of trastuzumab or T-DM1. The error bars indicate the S.D. $(n=3)$. In panels (a and $\mathbf{b}), P$-values versus untreated control were calculated by two-sided, unpaired Student's $t$-test $\left({ }^{\star} P<0.05,{ }^{* *} P<0.01\right)$. (c) HER2-positive and -negative breast cancer cell lines were treated with different concentrations of T-DM1 for $48 \mathrm{~h}$ to obtain $\mathrm{EC}_{50}$ values for clonogenicity and cytotoxicity. Using concentrations up to $10 \mu \mathrm{g} / \mathrm{ml}$, the $\mathrm{EC}_{50}$ values for HCC1806 and HCC1937 cells were not attained. (d) HER2 expression was analyzed by flow cytometry on $\mathrm{CD} 44^{\text {high }} \mathrm{CD} 24^{\text {high }}$ and $\mathrm{CD} 44^{\text {high }} \mathrm{CD} 24^{\text {low }}$ cells from a patient with metastasized HER2-positive breast cancer. Green curve: isotype control antibodies ( $10 \mu \mathrm{g} / \mathrm{ml})$, red curve: HER2 expression on CD44 ${ }^{\text {high }} \mathrm{CD} 24^{\text {low }}$ cells, blue curve: HER2 expression on CD44 ${ }^{\text {high }} \mathrm{CD} 24^{\text {high }}$ cells $(10 \mu \mathrm{g} / \mathrm{ml})$. CD24 ${ }^{\text {high }}$ and CD24 $4^{\text {low }}$ cell populations were separated by gating and showed similar binding of the isotype control antibody. The indicated values for the specific fluorescence intensities (SFIs) were obtained by dividing the signal obtained with the specific antibody by the signal obtained with the corresponding isotype control. Please note the logarithmic scale

autophagy was reported to be critical for the tumorigenicity of breast cancer stem-like/progenitor cells ${ }^{46-48}$ and found to positively regulate the $\mathrm{CD} 44^{\text {high }} \mathrm{CD} 24^{\text {low }}$ phenotype. ${ }^{49}$
In order to exclude artifacts depending on side effects of autophagy inhibitors, we used three different substances (3-methyl adenine, chloroquine and artesunate), which all 
a

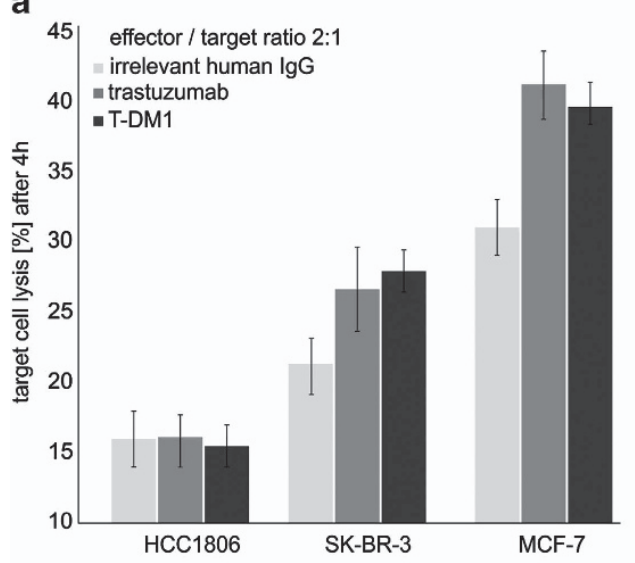

b

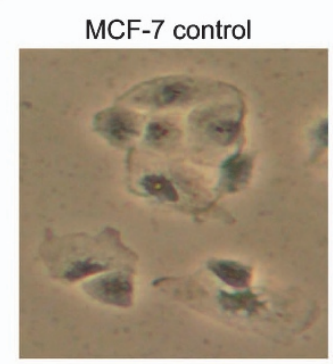

C

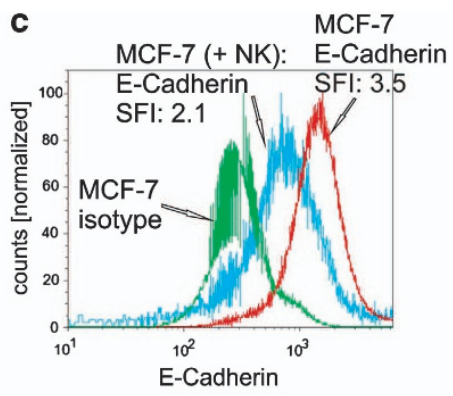
MCF-7 + NK cells

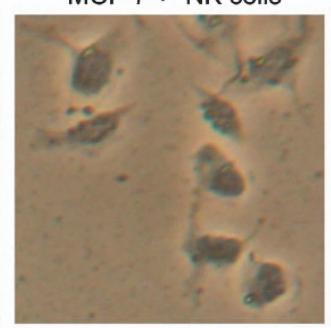

d

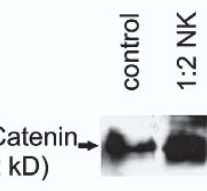

(92 kD)

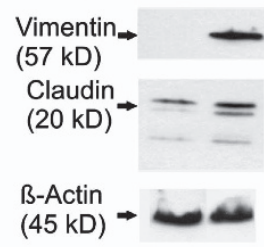

e

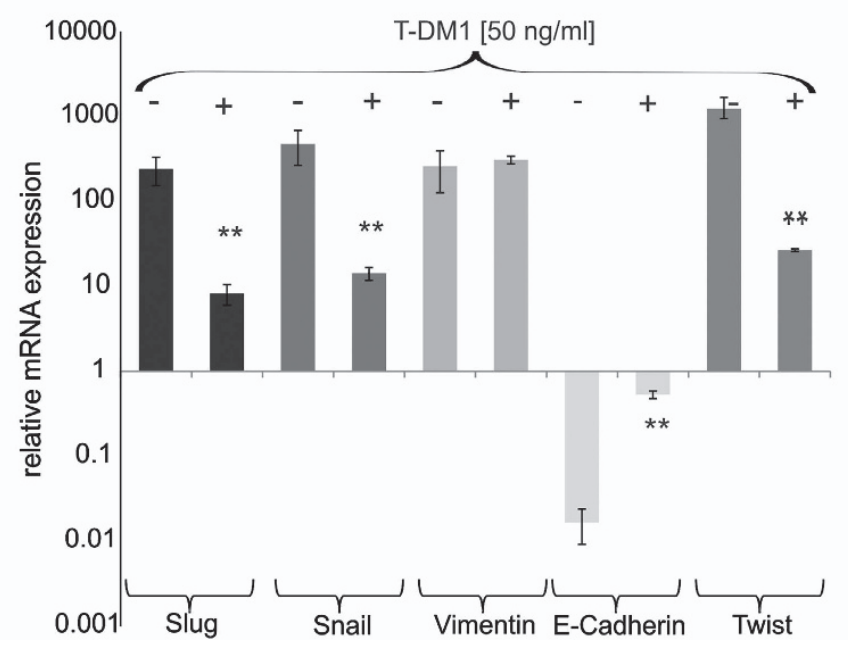

Figure 3 During coculture with NK cells, T-DM1 can induce ADCC in breast cancer cells and inhibit EMT. (a) HCC1806, SK-BR-3 or MCF-7 breast cancer cells were cocultured with NK cells for $4 \mathrm{~h}$, at a tumor-to-NK cell ratio of $1: 2$. For better discrimination, immune cells were stained with eFluor 670Cell Proliferation Dye, and tumor cells were stained with CFSE. Target cell lysis of breast cancer cells (as evidenced by CFSE loss) was determined after $4 \mathrm{~h}$ by FACS analysis. Normal human immunoglobulins $\mathrm{G}$ (IgGs) served as a control for the humanized antibody trastuzumab and its conjugate T-DM1 (all used at $50 \mathrm{ng} / \mathrm{ml}$ ). Data analysis was performed using an unpaired, two-sided Student's $t$-test. Results from three independent experiments were analyzed $\left({ }^{*} P<0.05,{ }^{* \star} P<0.01\right)$. (b) MCF-7 breast cancer cells were photographed before (left panel) and after (right panel) $16 \mathrm{~h}$ coculture with NK cells to visualize the changes regarding cellular morphology from the epithelial to a fibroblastic shape. (c) Flow cytometry was used to determine E-cadherin surface expression on MCF-7 breast cancer cells before and after $24 \mathrm{~h}$ of coculture with NK cells. Although the binding of a PerCP/Cy5.5-labeled isotype control of irrelevant specificity remained unaltered after coculture (green curve), the signals obtained with a similarly labeled anti-E-Cadherin antibody (clone 67A4) before and after coculture are shown in blue (before) and red (after), respectively. SFI values are indicated. (d) MCF-7 breast cancer cells were incubated for $24 \mathrm{~h}$ with NK cells, using a tumor cell-to-NK cell ratio of 1:2. After removal of non-adherent (i.e., NK) cells, protein lysates were prepared from the remaining adherent MCF-7 cells and tested for expression of $\beta$-catenin, vimentin and claudin by western blotting. $\beta$-Actin was used as a loading control. (e) Cocultures were set up as in panel (d). Where indicated, T-DM1 was added at a concentration of $50 \mathrm{ng} / \mathrm{ml}$. After $16 \mathrm{~h}$, NK cells were removed by washing, and RNA was extracted from the remaining adherent MCF-7 cells. The regulation of EMT markers was analyzed by Sybr-Green-based quantitative real-time PCR, using 18S rRNA as internal control 

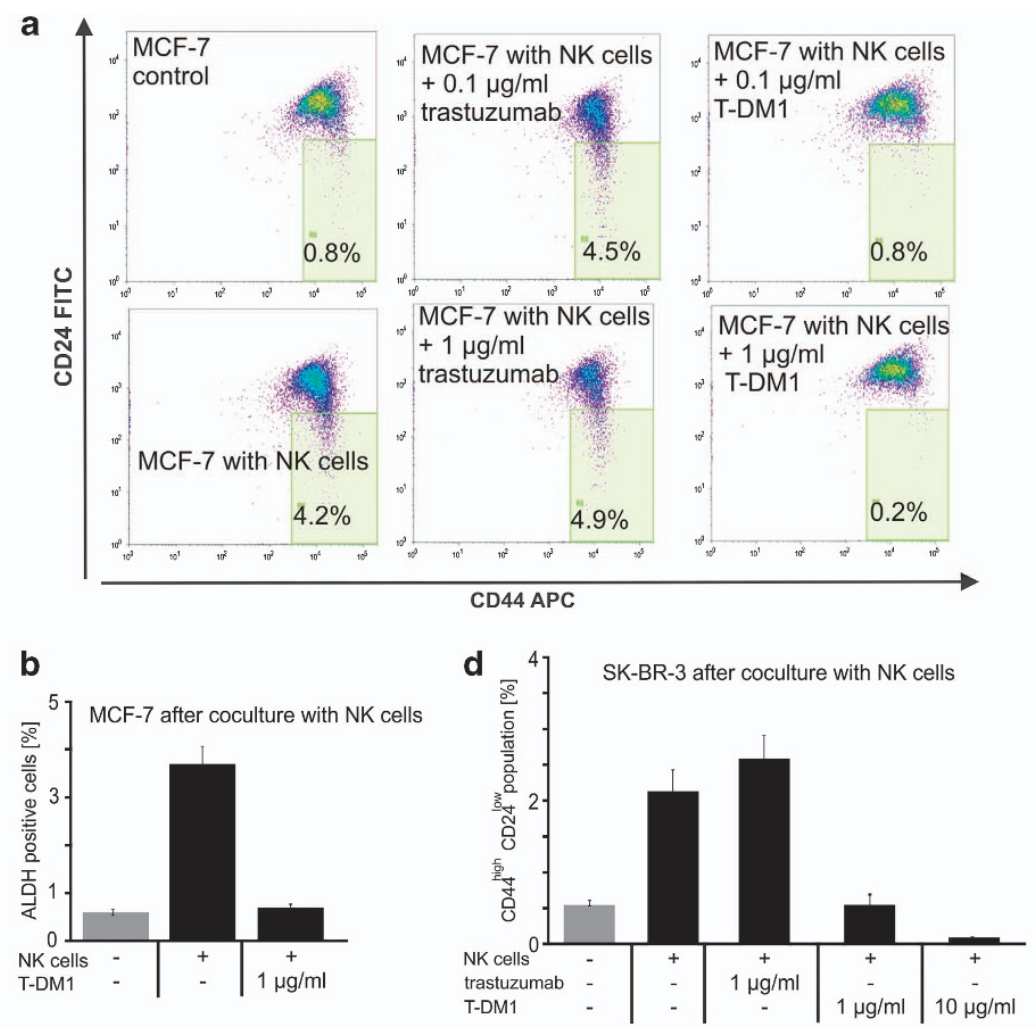

C

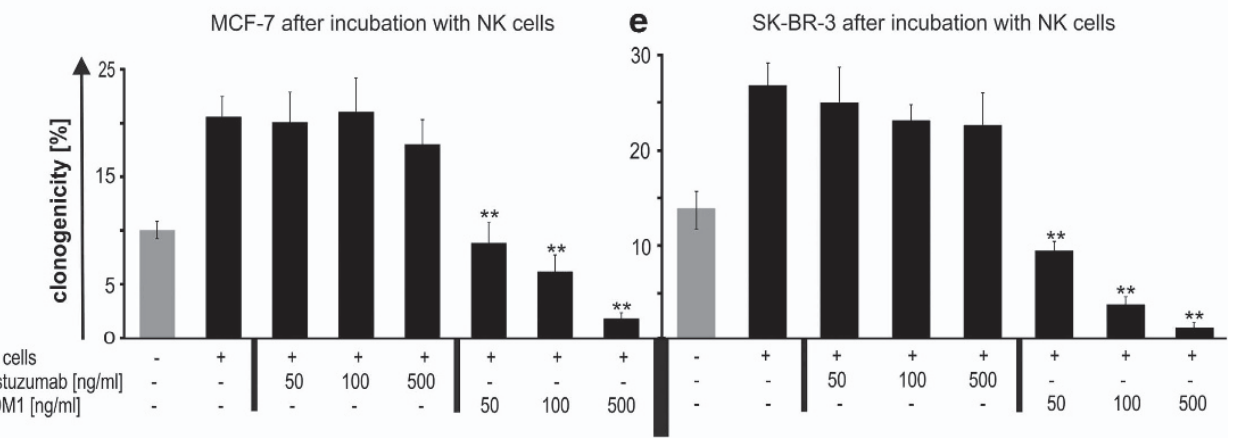

Figure 4 T-DM1 blocks the immune-mediated enrichment of CD44 ${ }^{\text {high }} \mathrm{CD} 24^{\text {low }}$ and ALDH ${ }^{+}$breast cancer CSCs. (a-e) MCF-7 (a-c) and SK-BR-3 (d and e) breast cancer cells were cocultured with NK cells for $16 \mathrm{~h}$, using a tumor cell-to-NK cell ratio of 1:2. Trastuzumab or T-DM1 was added where indicated. (a and d) Using fluorescently labeled antibodies against CD24 and CD44, the size of the CD44 ${ }^{\text {high }} \mathrm{CD} 24^{\text {low }}$ population was analyzed before and after incubation with polyclonal NK cells. In panel (b), the proportion of ALDH-expressing cells was assessed before (grey) and after (black) coculture with NK cells using the ALDEFLUOR reagent system. Cells displaying high levels of ALDH are identified via the enzymatic conversion of a fluorogenic dye that can be visualized by flow cytometry. Positivity in this assay is considered to be a characteristic trait of CSCs. In panels ( $\mathbf{a}, \mathbf{b}$ and $\mathbf{d}$ ), representative experiments are shown. (c and $\mathbf{e}$ ) MCF-7 (upper bar chart) and SK-BR-3 (lower bar chart) breast cancer cells were incubated for $16 \mathrm{~h}$ with NK cells, using a tumor cell-to-NK cell ratio of 1:2. T-DM1 or trastuzumab were added at the indicated concentrations. After $16 \mathrm{~h}$, clonogenicity of the surviving tumor cells was assessed as in Figure $2 \mathrm{~b}$. Clonogenicity indices for cells that had not been cocultured with NK cells are shown in grey. $P$-values for the effects of trastuzumab or T-DM1 were calculated by the two-sided unpaired Student's $t$-test using the respective coculture without antibody as relevant control $\left(n=3,{ }^{* *} P<0.01\right)$

caused an accumulation of the macroautophagy substrates LC3-II and p62 in MCF-7 cells. Quantification of the obtained western blotting data showed the strongest effect with chloroquine and a somewhat weaker efficiency for 3-methyladenine (Figure 5a). Consequently, 3-methyladenine ${ }^{50}$ chloroquine ${ }^{51}$ and artesunate ${ }^{52}$ all reduced the size of the $\mathrm{CD} 44^{\text {high }} \mathrm{CD} 24^{\text {low }}$ population (Figure $5 \mathrm{~b}$ ) and the clonogenicity of MCF-7 cells (Figure $5 \mathrm{c}$ ), up to a complete loss of clonogenicity and of CD44 ${ }^{\text {high }} \mathrm{CD} 24^{\text {low }}$ cells in the absence of acute cytotoxicity. Using artesunate, similar data were also obtained with primary breast cancer cells from pleural effusions (Figure 5d).

CD44 ${ }^{\text {high }}$ CD24 $4^{\text {low }}$ breast CSCs show increased autophagy leading to enhanced internalization of HER2 from the cell surface. Interestingly, it has already been hypothesized that autophagy might facilitate resistance against the small molecule HER2 receptor kinase inhibitor Lapatinib in HER2-positive breast cancer cells. ${ }^{53}$ Thus, we wondered whether the low HER2 surface levels on CD44 ${ }^{\text {high }} \mathrm{CD} 24^{\text {low }}$ 
a
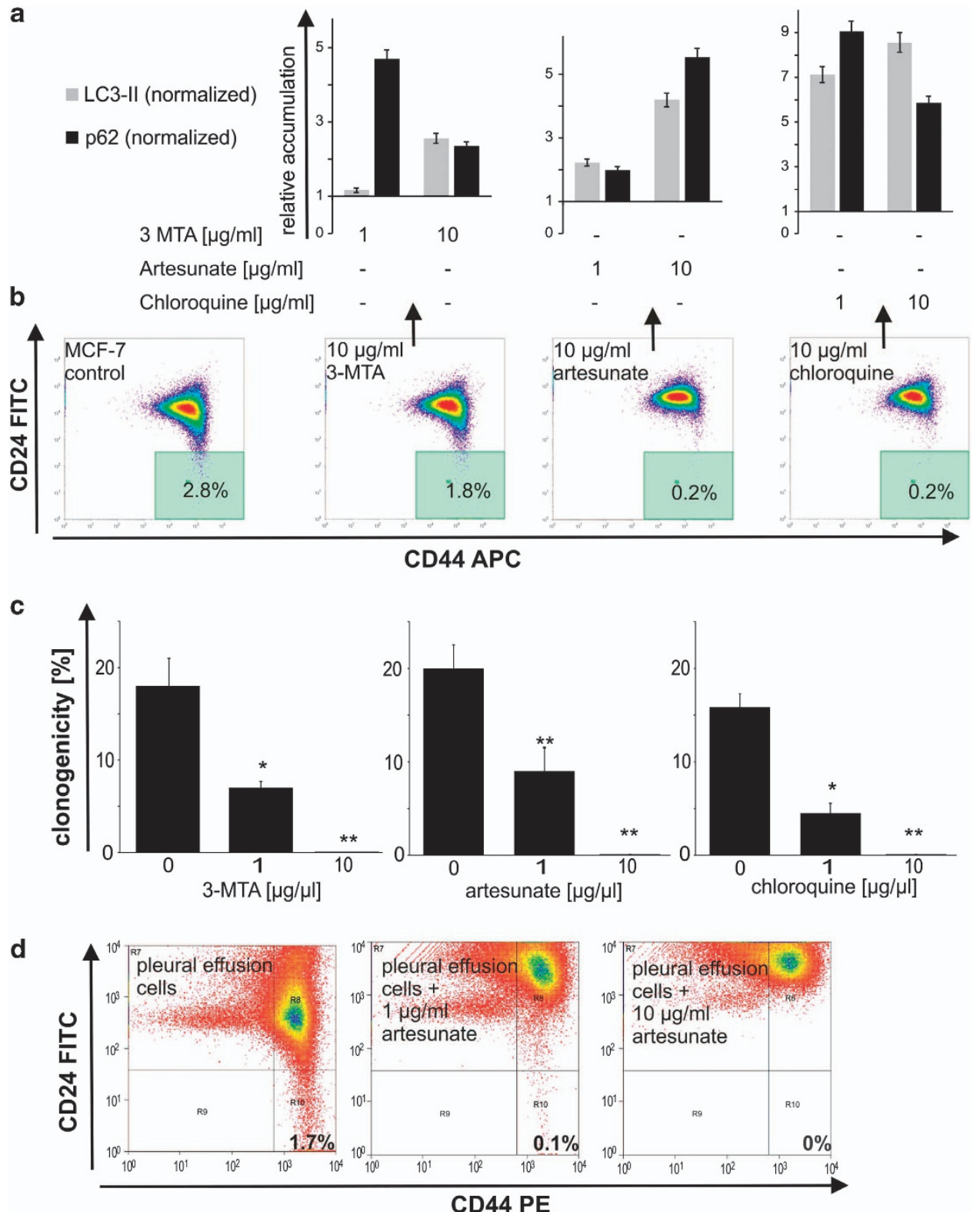

Figure 5 Enhanced autophagy is an essential requirement for clonogenic CD44 $4^{\text {high }} \mathrm{CD} 24^{\text {low }}$ stem cell-like breast cancer cells. (a-c) MCF-7 breast cancer cells were incubated with the autophagy inhibitors 3-methyladenine, chloroquine and artesunate for $24 \mathrm{~h}$. (a) Cell lysates were prepared from untreated and treated MCF-7 breast cancer cells and assayed for the expression of LC3-II and p62. $\beta$-Actin served as a loading control. Signals were quantified using Image J (U.S. National Institutes of Health, Bethesda, MD, USA; http://imagej.nih.gov/ij/), normalized to $\beta$-actin and the relative increase in non-degraded LC3-II and p62 was calculated. (b) The size of the $\mathrm{CD} 44^{\text {high }} \mathrm{CD} 24^{\text {low }} \mathrm{CSC}$ population was analyzed by flow cytometry before and after treatment. (c) MCF-7 breast cancer cells were treated with different concentrations of 3-methyladenine, chloroquine and artesunate for $24 \mathrm{~h}$. Thereafter, the ability of viable cells to form new colonies was analyzed as in Figure $2 b\left({ }^{*} P<0.05,{ }^{* *} P<0.01\right)$. (d) Primary tumor cells obtained from a pleural effusion of a patient with metastasized HER2-positive breast cancer, treated with different concentrations of artesunate and analyzed by flow cytometry for the presence of a CD44 ${ }^{\text {high }} \operatorname{CD} 24^{\text {low }} \operatorname{CSC}$ population

cells might be due to increased internalization of the receptor, which is a phenomenon known to occur in response to receptor activation. ${ }^{35}$ In line with this hypothesis, we observed a loss of the CD24 ${ }^{\text {low }} \mathrm{HER} 2^{\text {low }}$ subpopulation when autophagy was inhibited. HER2 expression on CD24 $4^{\text {high }}$ cells, however, remained unaltered (data not shown).

We thus assessed the internalization of the HER2 surface antigen in $\mathrm{CD} 44^{\text {high }} \mathrm{CD} 24^{\text {high }}$ and $\mathrm{CD} 44^{\text {high }} \mathrm{CD} 24^{\text {low }}$ cells using trastuzumab labeled with the fluorogenic dye pHrodo. This $\mathrm{pH}$-dependent dye experiences a steep increase in fluorescence upon acidification. As clathrin-coated or other vesicles used for endocytosis are characterized by a low $\mathrm{pH}$, this provided us with a tool to visualize internalization of the conjugated anti-HER2 antibody. Co-staining of trastuzumab-pHrodo-treated cells after $6 \mathrm{~h}$ confirmed that $>50 \%$ of the CD $44^{\text {high }}$ CD $24^{\text {low }}$ cells, but only $<2 \%$ of the more differentiated CD $444^{\text {high }} \mathrm{CD} 24^{\text {high }}$ cells, internalized pHrodo-labeled trastuzumab. Internalization could be prevented by addition of artesunate (Figure 6a). Irrespective of the tumor cell subset, no internalization was observed 

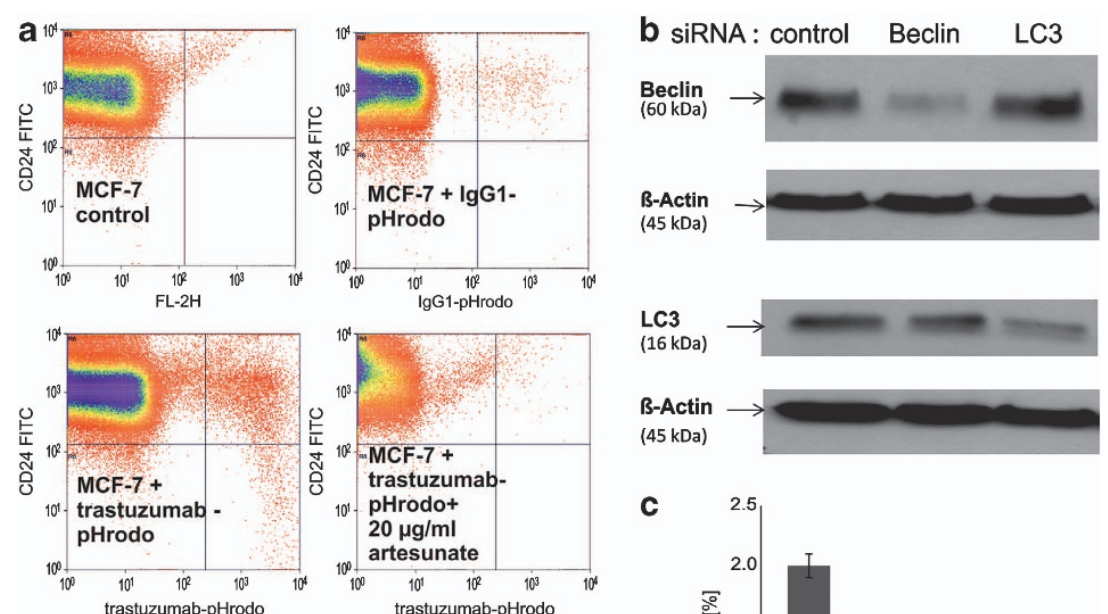

C
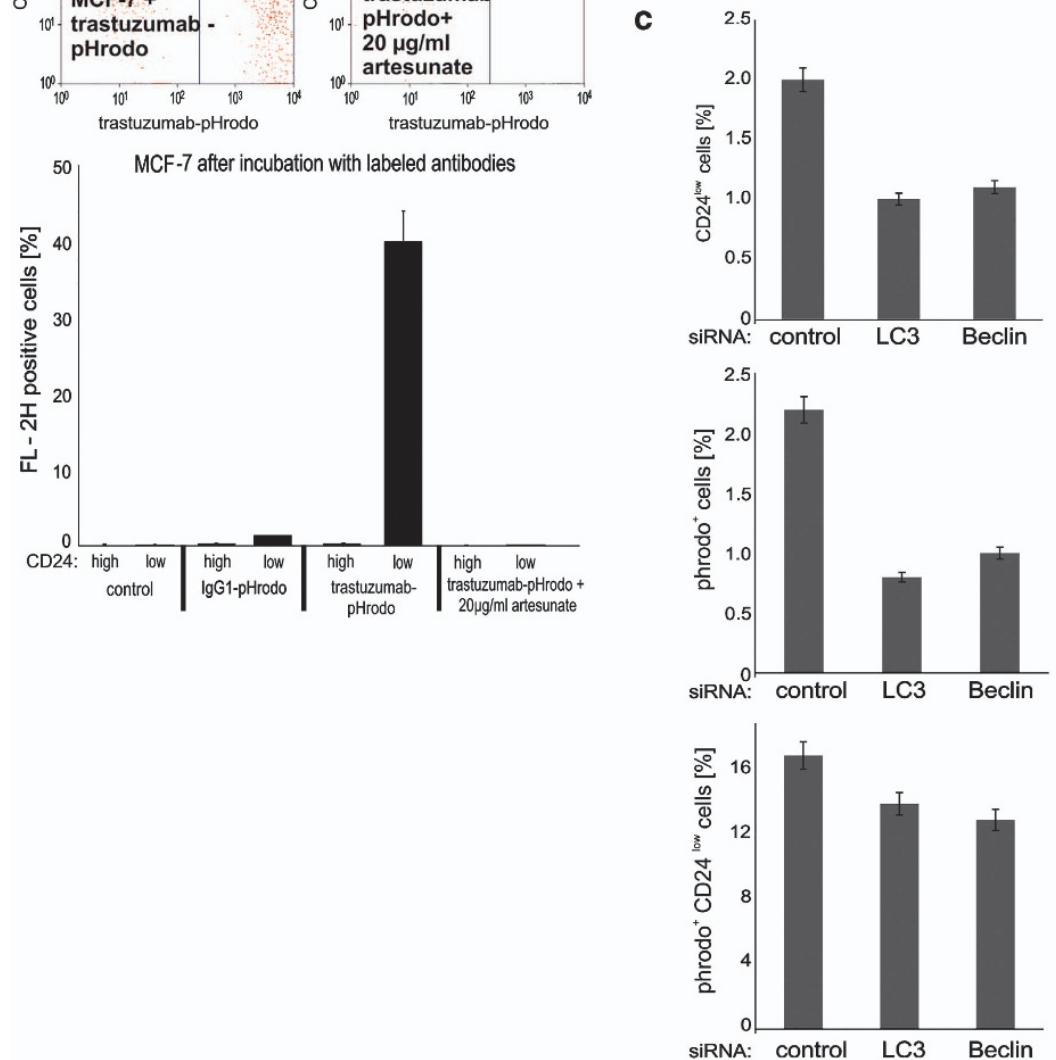

Figure 6 Internalization by increased autophagy represents an 'Achilles' heel' of CSCs with regard to T-DM1. (a) The HER2-specific antibody trastuzumab was labeled with the fluorogenic dye pHrodo. pHrodo shows a strong fluorescence in the $\mathrm{FL}-2 \mathrm{H}$ channel once the $\mathrm{pH}$ of its surroundings becomes more acidic, for example, upon internalization in endocytotic vesicles. Shown is the fluorescent signal from internalized trastuzumab-pHrodo against CD24 in CD44 ${ }^{\text {high }}$ cells, with CD44 ${ }^{\text {high }}$ CD24 ${ }^{\text {low }}$ cells representing the stem cell-like cancer cell population. Upper left: control MCF-7 cells, upper right: MCF-7 cells were incubated with pHrodo-labeled immunoglobulin G1 $\left(\mathrm{IgG}_{1}\right)$ isotype control antibodies and counter-stained with anti-CD24-FITC. Lower left: MCF-7 cells were incubated with pHrodo-labeled trastuzumab and stained with anti-CD24-FITC. Lower right: MCF-7 cells were incubated with pHrodo-labeled trastuzumab in the presence of the autophagy inhibitor artesunate $(20 \mu \mathrm{g} / \mathrm{ml})$ and stained with anti-CD24-FITC. Bar chart: Under the various applied conditions, the respective percentage of trastuzumab-pHrodo-internalizing cells was determined and evaluated separately for the CD24 $4^{\text {high }}$ and CD24 ${ }^{\text {low }}$ subsets. (b) Using TransIT TKO transfection reagent, MCF-7 breast cancer cells were transfected with $25 \mathrm{nM}$ of siRNA against Beclin (BECN1 no. s16537, Ambion) or LC3 (no. MAP1LC3A, Ambion) or with a universal negative siRNA control (Sigma). Forty-eight hours later, cells were lysed and the expression of Beclin, LC3 and $\beta$-actin was assayed in the various groups by western blotting. (c) MCF-7 cells were transfected with siRNA as in panel (c) before being incubated with trastuzumab-pHrodoas in panel (a). Staining for CD44 and CD24 followed by flow cytometric analysis enabled the quantification of CD44 ${ }^{\text {high }} \mathrm{CD} 24^{\text {low }}$ cells, of trastuzumabinternalising pHrodo ${ }^{\text {pos }}$ cells and of pHrodo ${ }^{\text {pos }} \mathrm{CD} 24^{\text {low }}$ cells shown in panel (c)

with the non-binding Rituximab-pHrodo conjugate (data not shown).

To further confirm that maintenance of the CD44 $4^{\text {high }}$ CD24 ${ }^{\text {low }} \mathrm{CSC}$-like state and internalization of pHrodo-labeled trastuzumab by these cells depends on autophagy, we sought to inhibit autophagy by siRNAs against Beclin and LC3 (Figure 6b). Although downregulation of these essential mediators of autophagy was incomplete, siRNA treatment was still sufficient to reduce the extent of the CD $44{ }^{\text {high }} \mathrm{CD} 24^{\text {low }}$ population and the percentage of pHrodo-positive cells (Figure 6c). The fact that the remaining $\mathrm{CD} 44^{\text {high }} \mathrm{CD} 24^{\text {low }}$ cells showed a hardly reduced uptake of pHrodo might suggest that the loss of the CD2 $4^{\text {low }}$ signature precedes or coincides with the reduced level of internalization. 
Importantly, as pHrodo and emtansine are similarly small in size, and as they are both coupled to the same large antibody, it may be assumed that T-DM1 will show a similar behavior as this fluorogenic conjugate. We thus propose that CD44 $4^{\text {high }}$ $\mathrm{CD} 24^{\text {low }}$ breast cancer CSCs show a high level of internalization with regard to HER2 and thus evade effector mechanisms, such as ADCC. However, by this same property these cells will preferentially internalize antibody-drug conjugates. This can not only explain the highly efficient targeting of clonogenic CD44 ${ }^{\text {high }}$ CD2 $4^{\text {low }}$ cells by T-DM1 but also provide a more general rationale for the targeting of breast cancer CSCs with antibody-drug conjugates against HER2 or other oncogenic growth factor receptors.

\section{Discussion}

The HER2-specific antibody trastuzumab ${ }^{10}$ has significantly increased overall survival in patients suffering from HER2positive breast cancer. Moreover, a recent study has also revealed a role for HER2 in the CSC subset of cell lines (including MCF-7) which are not commonly classified as HER2 overexpressing. ${ }^{6}$ Likewise, synergy between trastuzumab and paclitaxel or docetaxel had also been reported in such cell lines. ${ }^{38}$ Accordingly, more patients than previously anticipated might benefit from treatment with anti-HER2 antibodies. Unfortunately, however, the majority of patients treated with trastuzumab experience relapse at some time after treatment. Thus, a better understanding of the mechanism(s) underlying this resistance might pave the way towards more effective strategies. In our previous studies, we could demonstrate in vitro that the binding of trastuzumab 'labels' HER2-positive breast cancer cells for Fc $\gamma$-dependent recognition by NK cells, ${ }^{16}$ thereby inducing ADCC. ${ }^{12,13}$ This important immune-stimulatory effect has been preserved in the antibody-drug conjugate T-DM1, which has retained the Fc $\gamma$-part of trastuzumab (Figure 3a). Also inhibition of HER2 signaling, as evidenced by reduced activation of the phosphatidylinositol 3'-kinase-AKT pathway, is similarly achieved by both trastuzumab and T-DM1 (data not shown). However, T-DM1 combines the mechanisms of action of trastuzumab with the additional specific application of the potent chemotherapeutic DM1. ${ }^{31,32}$

Unlike trastuzumab, T-DM1 thus induced cell cycle arrest and significant cell death in HER2-positive tumor cells that is

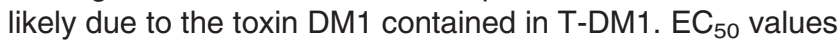
over $48 \mathrm{~h}$ were mostly $\geq 10 \mu \mathrm{g} / \mathrm{ml}$ (Figures $1 \mathrm{~b}$ and $\mathrm{c}$ ), which might be hard to achieve in patients. Using clinically relevant concentrations $(3 \mu \mathrm{g} / \mathrm{ml})^{54}$ of T-DM1, a significant proportion of target cells survived in vitro that could point towards chemoresistance. However, HER2-positive tumor cells surviving a treatment with T-DM1 displayed drastically reduced clonogenicity (Figures $2 \mathrm{a}-\mathrm{c}$ ), even at T-DM1 concentrations as low as $50 \mathrm{ng} / \mathrm{ml}$. Likewise, T-DM1 incubation almost abrogated the clonogenicity of sorted CD44 ${ }^{\text {high }}$ $\mathrm{CD} 24^{\text {low }}$ cells, whereas trastuzumab treatment showed no comparable effect on this highly tumorigenic and poorly immunogenic subset (Figure 2b). This suggests that T-DM1 is far more effective against CSC than trastuzumab. In fact, the major limitation encountered in our previous study was the insufficient targeting of $\mathrm{CD} 44^{\text {high }} \mathrm{CD} 24^{\text {low }} \mathrm{HER} 2^{\text {low }}$ cells either with trastuzumab alone or in conjunction with NK cells. ${ }^{16}$ Based on the evidence that this subset possesses characteristics of the so-called 'tumor-initiating' or 'metastasis-initiating' or 'CSCs', ${ }^{17}$ a lack of activity against this subpopulation may explain the high rate of recurrence after treatment.

CSCs, however, constitute a rather dynamic subset. We and others have observed ${ }^{26}$ that 'unproductive' (i.e., non-lytic) interactions between immune and tumor cells induce EMT in breast cancer cells, which reprograms previously differentiated cancer cells towards a CSC-like phenotype. ${ }^{22}$ Accordingly, tumor cell cultures that had interacted with NK cells showed morphological changes towards a mesenchymal phenotype (Figure 3b), downregulation of the epithelial cell adhesion molecule E-Cadherin (Figure $3 \mathrm{c}$ ), upregulation of EMT markers (Figures 3d and e), more CD44 ${ }^{\text {high }} C D 24^{\text {low }}$ (Figures $4 \mathrm{a}$ and $\mathrm{d}$ ) and $\mathrm{ALDH}^{+}$(Figure 4b) cells and enhanced clonogenicity (Figures $4 \mathrm{c}$ and $\mathrm{e}$ ). Addition of T-DM1 to the coculture, however, prevented this expansion of the CSC population (Figures $3 e$ and 4). This left us with two possible explanations: either tumor cells that had survived the treatment were 'sufficiently damaged' to lose all stem cell-like properties or the antibody-drug conjugate might preferentially target highly clonogenic 'CSCs' - in spite of their low HER2 surface expression (Figure 2d). This prompted us to investigate the possibility of enhanced internalization by CSCs. In fact, the CSC phenotype has repeatedly been linked to autophagy, ${ }^{49,55,56}$ a tightly regulated catabolic process involving the degradation of a cell's own components through the lysosomal machinery. On the one hand, autophagy helps to keep up a balance between degradation, synthesis and recycling of cellular products and allows stressed or starving cells to recycle nutrients from unnecessary processes to more essential metabolic tasks. On the other hand, autophagy leads to a constant recycling of cellular components and thus enables longevity ${ }^{57}$ and maintenance of a stem cell-like phenotype not only in hematopoietic ${ }^{58}$ but also in breast cancer CSCs. ${ }^{48}$ In line with these reports, autophagy inhibitors (chloroquine, 3'-methyladenine or artesunate) ${ }^{51,59}$ abrogated CD44 ${ }^{\text {high }} \mathrm{CD} 24^{\text {low }} \mathrm{Her} 2^{\text {low }}$ cells and clonogenicity in primary breast cancer cells from pleural effusions and in breast cancer cell lines (Figures $5 b$ and d). Most importantly, however, we measured internalization of trastuzumab by covalently coupling the fluorogenic dye pHrodo to the antibody. This revealed a preferential internalization of the conjugated anti-HER2 antibody by CD $44{ }^{\text {high }} \mathrm{CD} 24^{\text {low }}$ cells that could be abrogated by inhibiting autophagy (Figure 6a). Unspecific binding via the pHrodo moiety or the human IgG backbone was excluded by use of the pHrodo-labeled humanized anti-CD20 antibody rituximab. The link between autophagy, $\mathrm{CD} 44^{\text {high }} \mathrm{CD} 24^{\text {low }} \mathrm{CSC}$ and internalization of labeled trastuzumab was further confirmed by siRNAmediated downregulation of LC3 or Beclin (Figure 6b), which resulted in a significantly smaller $\mathrm{CD} 44^{\text {high }} \mathrm{CD} 24^{\text {low }} \mathrm{CSC}$ subset and in reduced internalization of pHrodo-labeled trastuzumab. Interestingly, those cells that retained the CD24 $4^{\text {low }}$ phenotype also showed unaltered internalization. We thus propose that the low HER2 (and, most likely also the low CD24) surface expression on CD44 ${ }^{\text {high }} \mathrm{CD} 24^{\text {low }}$ cells is mainly due to internalization via autophagy. This, once again, 
confirms that autophagy enables constant renewal of these cells and may be protective against most therapeutic insults, including immune-mediated destruction via ADCC. However, when it comes to antibody-drug conjugates, this mechanism constitutes an 'Achilles' heel' that may be therapeutically exploited by T-DM1. Considering that the targeting of these cells is thought to be essential for a successful cancer therapy, our in vitro data thus suggest that T-DM1 holds great promise for future treatment of early and metastatic HER2-positive breast cancer. In fact, first results from the EMILIA trial, a phase III study in which 991 women with locally advanced or metastatic, unresectable, trastuzumab- and taxane-treated, HER2-positive breast cancer were enrolled showed longer progression-free survival (9.6 versus 6.4 months) and a superior safety profile for T-DM1 against the combination of capecitabine with lapatinib. ${ }^{60}$

Further trials (MARIANNE, TH3RESA) are ongoing. From a mechanistic point of view, it is interesting to note that a tubulin inhibitor can prevent the unwanted induction of tumor stem cell characteristics. In line with this notion, pretreatment of cancer cells with paclitaxel (Taxol) likewise prevented the induction of EMT and of stem cell-like features (data not shown). Thus, tubulin-dependent processes seem to have a seminal role for CSC induction. It may thus be speculated whether the induced CD $44^{\text {high }} \mathrm{CD} 24^{\text {low }}$ cells actually originate from more differentiated tumor cells via (induced) asymmetric cell divisions. In any case, these data show that the coupling of a potent inhibitor of the mitotic spindle to trastuzumab was a good choice for T-DM1. Moreover, the combination of the anti-proliferative and immune-activating effect of trastuzumab at the cell surface with intracellular delivery of a potent toxin upon endocytosis could serve as a template for further antibody-drug conjugates. Such novel therapeutics might not only be well tolerated but also be particularly effective against CSCs with their high internalization rate.

\section{Materials and Methods}

Cell culture and reagents. MCF-7, MDA-MB-231, BT-474, HCC1937, HCC1806 and SK-BR-3 breast cancer cells were obtained from the American Type Culture Collection (Manassas, VA, USA) and the Deutsche Sammlung für Mikroorganismen und Zellkulturen (DSMZ, Braunschweig, Germany), authenticated and cultured as indicated by the supplier. Primary tumor cells were obtained from pleural effusions of patients undergoing puncture for the palliative treatment of metastasized breast cancer at our institution. Further investigation of these cells was approved by both the patients and the local ethics committee. Cells were centrifuged, washed with PBS, and transferred to L-valine-free, D-valinecontaining Dulbecco's Modified Eaglés Medium supplemented with 2\% heatinactivated FCS (Biochrom, Berlin, Germany), penicillin (100 IU/ml) and streptomycin $(100 \mathrm{lU} / \mathrm{ml})$ (all from PAA, Cölbe, Germany). Non-adherent cells were removed by washing after $24 \mathrm{~h}$. Fibroblast growth was suppressed due to the lack of L-valine. Autophagy inhibitors (3-methyl adenine, artesunate and chloroquine) were obtained from Sigma (Deisenhofen, Germany).

Cytotoxicity and cell cycle assays. Breast cancer cells were treated with different concentrations of T-DM1 and trastuzumab as indicated. Cell density after drug treatment was assessed by crystal violet staining. As this assay is based on the quantification of adherent cells, microscopy was used to confirm that dying cells became round and detached. As an additional control, the metabolic WST-1 assay (Roche, Mannheim, Germany) was used according to the manufacturer's instructions. For cell cycle analysis, cells were detached, fixed and permeabilized for at least $1 \mathrm{~h}$ in ice-cold $70 \%$ ethanol and washed with PBS before their DNA was stained with propidium iodide (PI). RNA was simultaneously digested with DNAse-free RNAse A (Carl Roth, Karlsruhe, Germany). PI intercalates into DNA with no sequence preference and thus enables the assessment of the cellular DNA content in the FL-2A channel of the FACSCalibur flow cytometer (BD Biosciences, Heidelberg, Germany). Doublets were excluded via the FL-2W channel. Cells containing less than a complete set of chromosomes (i.e., $2 n$ ) are considered to be dead.

Clonogenicity assays. Clonogenicity assays are in vitro cell survival assays based on the ability of single cells to establish a new colony. The assay essentially investigates the proportion of cells that can undergo 'unlimited' division. Breast cancer cells were treated as indicated before being seeded at low density on low-attachment plastic material (Greiner BioOne, Frickenhausen, Germany). After 2-3 weeks, colonies were fixed, stained with crystal violet $(0.5 \% \mathrm{w} / \mathrm{v})$ and counted. Stained colonies consisting of at least 50 cells were visible without the use of a microscope.

Flow cytometric analysis of surface expression levels and cell sorting. Cells were either mechanically or enzymatically detached using Accutase (PAA), blocked and stained with $10 \mu \mathrm{g} / \mathrm{ml}$ Trastuzumab or $10 \mu \mathrm{g} / \mathrm{ml}$ T-DM1 (Genentech, Burlingame, CA, USA) followed by a Cy5-conjugated goat anti-human IgG (Rockland Immunochemicals, Gilbertsville, PA, USA) detection antibody. Simultaneously, CD44-RPE (Clone 2BJ18, BioLegend, San Diego, CA, USA), CD24-FITC (clone SWA-11, kindly provided by Professor Peter Altevogt, German Cancer Research Centre, Heidelberg, Germany) and the life stain 7-aminoactinomycin D (Sigma) were applied and analyzed on a FACSCalibur or an Attune flow cytometer (Life Technologies, Darmstadt, Germany). For E-Cadherin surface staining, a PerCP/Cy5.5-labeled anti-human CD324/ECadherin antibody (Clone 67A4) and a corresponding isotype control (Clone MOPC-21), both from BioLegend, were used. Where appropriate, expression levels are indicated as specific fluorescence intensity values, which are obtained by dividing the fluorescence intensity detected with the specific antibody by the signal measured with the isotype-matched control antibody. For fluorescenceactivated cell sorting, the stained cells were separated twice on a Digital FACSVantage (BD Biosciences), first in yield and then in purity mode.

ALDH assay. The ALDEFLUOR assay (STEMCELL Technologies, Grenoble, France) enables the identification of stem and progenitor cells based on their high expression of ALDH1. This enzyme converts the fluorogenic substrate BODIPYaminoacetaldehyde into a green fluorescent dye that can be visualized by flow cytometry. As the ALDEFLUOR reaction product will leak out of dead cells, only viable cells are identified by this assay. Transporter-mediated exclusion of the dye from stem cells is prevented by multi-drug reporter inhibition with a verapamilcontaining inhibitor contained in the kit. Tumor cells were treated with different concentrations of drugs for variable intervals of time. Afterwards, the ALDEFLUOR test was conducted according to the manufacturer's instructions.

NK cell preparation and cytotoxicity assays. Peripheral blood lymphocytes were obtained from healthy volunteers by density gradient centrifugation (Biocoll, Biochrom) and cultured for 8-11 days on irradiated (30 Gy) RPMI8866 feeder cells to obtain polyclonal NK cell populations (30). NK cell-mediated lysis of MCF-7 or MDA-MB-231 cells was assessed by modified fluorometric assessment of T lymphocyte antigen specific lysis assays. ${ }^{41}$ NK cells were thus labeled with eFluor 670 Cell Proliferation Dye (ebioscience, Frankfurt, Germany) while target cells $\left(2 \times 10^{5} /\right.$ well) were stained with carboxyfluorescein diacetate succinimidyl ester (CFSE) (Invitrogen, Karlsruhe, Germany). Cocultures were set up using different effector:target ratios, and lytic activity was assessed after $16 \mathrm{~h}$ by flow cytometric detection of CFSE $^{\text {dim }}$ cells among the eFluor 670-negative target cell population. Values were corrected for spontaneous leakage of CFSE.

Immunoblot analysis. Regulation of EMT-related proteins in MCF-7 cells that had been cocultured with NK cells was analyzed by immunoblot. In short, NK cells were removed by washing. Adherent cells were detached, collected by centrifugation, washed with PBS and lysed in protein lysis buffer containing $50 \mathrm{mM}$ Tris- $\mathrm{HCl}$ (tris(hydroxymethyl)aminomethane-hydrochloric acid) pH 8.0 (Sigma)), $120 \mathrm{mM}$ sodium chloride, $5 \mathrm{mM}$ EDTA, $2 \mu \mathrm{g} / \mathrm{ml}$ Aprotinin, $10 \mu \mathrm{g} / \mathrm{ml}$ Leupeptin, $1 \mathrm{mM}$ PMSF, $10 \mathrm{nM}$ sodium fluoride (all purchased from Carl Roth, Karlsruhe, Germany), $0.5 \%$ Nonidet P-40 and $1 \mathrm{mM}$ sodium orthovanadate (both from Applichem GmbH, Darmstadt, Germany). Proteins were separated on $8-15 \%$ polyacrylamide (Carl Roth) gels under reducing conditions, transferred to 
Nitrocellulose (Protran Transfer Membrane, Whatman, Dassel, Germany), which was blocked in PBS containing 5\% skimmed milk powder and $0.05 \%$ Tween20 (both from Carl Roth), and incubated overnight at $4{ }^{\circ} \mathrm{C}$ with the following antibodies (all from Cell Signaling Technology, Danvers, MA, USA): anti-human LC3 (clone D3U4C), anti-human Beclin (clone D40C5), anti-human B-Catenin (clone D10A8), anti-human Claudin (no. 4933), anti-human Vimentin (clone D21H3), anti-human pAKT (clone Ser473), and anti-human AKT (no. 9272). Antibodies against p62 (Poly6477) and against $\beta$-actin (Poly6221), which served as loading control, were from BioLegend. Proteins were visualized using horseradish peroxidase-coupled anti-mouse or anti-rabbit IgG secondary antibody (Cell Signaling) and homemade enhanced chemiluminescence (ECL) solution. ECL solution was prepared by mixing $0.25 \mathrm{mg} / \mathrm{ml}$ Luminol (Carbosynth Ltd, Berkshire, UK) in $0.1 \mathrm{M}$ Tris-HCL (pH 8.6) with $1.1 \mathrm{mg} / \mathrm{ml}$ para-hydroxycoumaric acid (Sigma-Aldrich, Taufkirchen, Germany) and $0.03 \%$ hydrogen peroxide (Carl Roth) at a 10:1:0.003 ratio.

qRT-PCR. Total RNA was prepared using TriFast (Peglab, Erlangen, Germany) and transcribed with the iScript cDNA Synthesis kit (Bio-Rad, Munich, Germany). For real-time PCR, CDNA amplification was monitored using the ABsolute QPCR SYBR Green Low Rox mix (ABgene, Epsom, UK) on the ABI PRISM 7500 Sequence Detection System (Applied Biosystems, Weiterstadt, Germany). To this aim, 40 cycles of a two-step PCR protocol $\left(95^{\circ} \mathrm{C}\right.$ for $15 \mathrm{~s}, 60^{\circ} \mathrm{C}$ for $\left.1 \mathrm{~min}\right)$ were performed. The following primers were used:

18S up: 5'-CGGCTACCACATCCAAGGAA-3'; 18S down: $5^{\prime}$-GCTGGAAT TACCGCGGCT-3'; Snail up: 5'-CTGCTCCACAAGCACCAAGAGTC-3'; Snail down: $5^{\prime}$-CCAGCTGCCCTCCCTCCAC-3'; $\beta$-actin up: $5^{\prime}$-TGTTTGAGACCTT CAACACCC-3'; $\beta$-actin down: $5^{\prime}$-AGCACTGTGTTGGCGTACAG-3'; Slug up: 5'-GGGGAGAAGCCTTTTTCT TG-3'; Slug down: 5'-TCCTCATGTTTGTGCA GGAG-3'; Vimentin up: $5^{\prime}$-GAGAATTTGCCGTTGAAGC-3'; Vimentin down: 5'-GCTTCCTGTAGGTGGCAATC-3'; Twist up: 5'-GGAGTCCGCAGTCTTA CGAG-3'; Twist down: 5'-TCTGGAGGACCTGGTAGAG-3'; E-Cadherin up: 5'-CCGAGATGGGGTTGATAATG-3'; and E-Cadherin down: 5'-ACAGTGG CCACCTACAAAG- $3^{\prime}$. Data analysis was done using the $\Delta \Delta \mathrm{C}_{\mathrm{T}}$ method for relative quantification. Dissociation curves confirmed the presence of a single specific PCR product.

pHrodo assay. HER2-specific antibodies were labeled with the fluorogenic dye pHrodo (Life Technologies, INVITROGEN CORPORATION, Burlington, ON, Canada) according to the manufacturer's instructions. pHrodo shows increased fluorescence in the $\mathrm{FL}-2 \mathrm{H}$ channel as the $\mathrm{pH}$ of its surroundings becomes more acidic, for example, upon internalization in endocytotic vesicles. With respect to breast cancer cells, pHrodo-labeled humanized anti-CD20 antibody Rituximab (Rituxan) was used as a non-binding control.

siRNA transfection. In all, $2 \times 10^{5}$ MCF- 7 cells were seeded in a six-well plate. Twenty-four hours later, they were transfected with $25 \mathrm{nM}$ of siRNA against Beclin (BECN1 no.s16537) or LC3 (MAP1LC3A, no. s39155, both from Ambion, Life Technologies, Darmstadt, Germany) or with a universal negative siRNA control (Sigma), using $10 \mu \mathrm{l}$ of TransIT-TKO Transfection Reagent (Mirus, Madison, WI, USA). Forty-eight hours later, cells were lysed, and the expression levels of Beclin, LC3 and $\beta$-actin were assayed in the various groups by western blotting. Incubation with trastuzumab-pHrodo and subsequent flow cytometric analysis were performed as described above.

Statistics. Experiments were performed at least three times with similar results, and representative experiments are shown. S.Ds. for flow cytometry data were calculated by using the Summit software (Beckman Coulter, Krefeld, Germany). Analysis of significance was performed using an unpaired, two-sided Student's $t$-test.

\section{Conflict of Interest}

$\mathrm{AH}$ participated as a consultant in advisory boards for Roche and received honoraria from Roche. The remaining authors declare no conflict of interest.

Acknowledgements. We thank Dr. Peter Altevogt (Deutsches Krebsforschungszentrum, Heidelberg, Germany) for providing the CD24 antibody, Christian Linden for cell sorting, Birgitt Fischer for excellent technical assistance and Itsaso Montalban, Anoop Chandran and Markus Junker for valuable discussions. Grant support: This work was supported by a grant to JW and AH from F Hoffmann-La Roche/Genentech, a member of the Roche Group. VB is a fellow the German research council (DFG)-sponsored Graduate School for Life Sciences (GSLS) Würzburg. RGS is a member of the clinician scientist training program 'Interdisciplinary Translational Immunology' (Else-Kröner Forschungskolleg Würzburg), which is supported by the Else-Kröner Fresenius foundation.

1. Gschwind A, Fischer OM, Ullrich A. The discovery of receptor tyrosine kinases: targets for cancer therapy. Nat Rev Cancer 2004; 4: 361-370.

2. Monsey J, Shen W, Schlesinger P, Bose R. Her4 and Her2/neu tyrosine kinase domains dimerize and activate in a reconstituted in vitro system. J Biol Chem 2010; 285: 7035-7044.

3. Wiseman SM, Makretsov N, Nielsen TO, Gilks B, Yorida E, Cheang M et al. Coexpression of the type 1 growth factor receptor family members HER-1, HER-2, and HER-3 has a synergistic negative prognostic effect on breast carcinoma survival. Cancer 2005; 103: 1770-1777.

4. Slamon DJ, Clark GM, Wong SG, Levin WJ, Ullrich A, McGuire WL. Human breast cancer: correlation of relapse and survival with amplification of the HER-2/neu oncogene. Science 1987; 235: 177-182.

5. Bose R, Kavuri SM, Searleman AC, Shen W, Shen D, Koboldt DC et al. Activating HER2 mutations in HER2 gene amplification negative breast cancer. Cancer Discov 2012; 3: 224-237.

6. Ithimakin S, Day KC, Malik F, Zen Q, Dawsey SJ, Bersano-Begey TF et al. HER2 drives luminal breast cancer stem cells in the absence of HER2 amplification: implications for efficacy of adjuvant trastuzumab. Cancer Res 2013; 73: 1635-1646.

7. Bang YJ, Van Cutsem E, Feyereislova A, Chung HC, Shen L, Sawaki A et al. Trastuzumab in combination with chemotherapy versus chemotherapy alone for treatment of HER2-positive advanced gastric or gastro-oesophageal junction cancer (ToGA): a phase 3 , open-label, randomised controlled trial. Lancet 2010; 376: 687-697.

8. Cobleigh MA, Vogel CL, Tripathy D, Robert NJ, Scholl S, Fehrenbacher $L$ et al. Multinational study of the efficacy and safety of humanized anti-HER2 monoclonal antibody in women who have HER2-overexpressing metastatic breast cancer that has progressed after chemotherapy for metastatic disease. J Clin Oncol 1999; 17: 2639-2648.

9. Joensuu H, Kellokumpu-Lehtinen PL, Bono P, Alanko T, Kataja V, Asola R et al. Adjuvant docetaxel or vinorelbine with or without trastuzumab for breast cancer. N Engl J Med 2006; 354: 809-820.

10. Slamon DJ, Leyland-Jones B, Shak S, Fuchs H, Paton V, Bajamonde A et al. Use of chemotherapy plus a monoclonal antibody against HER2 for metastatic breast cancer that overexpresses HER2. N Engl J Med 2001; 344: 783-792.

11. Liang K, Lu Y, Jin W, Ang KK, Milas L, Fan Z. Sensitization of breast cancer cells to radiation by trastuzumab. Mol Cancer Ther 2003; 2: 1113-1120.

12. Beano A, Signorino E, Evangelista A, Brusa D, Mistrangelo M, Polimeni MA et al. Correlation between NK function and response to trastuzumab in metastatic breast cancer patients. J Transl Med 2008; 6: 25.

13. Hudis CA. Trastuzumab-mechanism of action and use in clinical practice. N Engl J Med 2007; 357: 39-51.

14. Clynes RA, Towers TL, Presta LG, Ravetch JV. Inhibitory Fc receptors modulate in vivo cytotoxicity against tumor targets. Nat Med 2000; 6: 443-446.

15. Kohrt HE, Houot R, Weiskopf K, Goldstein MJ, Scheeren F, Czerwinski D et al. Stimulation of natural killer cells with a CD137-specific antibody enhances trastuzumab efficacy in xenotransplant models of breast cancer. J Clin Invest 2012; 122: 1066-1075.

16. Reim F, Dombrowski $Y$, Ritter C, Buttmann M, Häusler S, Ossadnik M et al. Immunoselection of breast and ovarian cancer cells with trastuzumab and natural killer cells: selective escape of CD44high/CD24low/HER2low breast cancer stem cells. Cancer Res 2009; 69: 8058-8066.

17. Al-Hajj M, Wicha MS, Benito-Hernandez A, Morrison SJ, Clarke MF. Prospective identification of tumorigenic breast cancer cells. Proc Natl Acad Sci USA 2003; 100: 3983-3988.

18. Battula VL, Shi Y, Evans KW, Wang RY, Spaeth EL, Jacamo RO et al. Ganglioside GD2 identifies breast cancer stem cells and promotes tumorigenesis. J Clin Invest 2012; 122: 2066-2078.

19. Charafe-Jauffret E, Ginestier C, lovino F, Tarpin C, Diebel M, Esterni B et al. Aldehyde dehydrogenase 1-positive cancer stem cells mediate metastasis and poor clinical outcome in inflammatory breast cancer. Clin Cancer Res 2010; 16: 45-55.

20. Al-Ejeh F, Smart CE, Morrison BJ, Chenevix-Trench G, Lopez JA, Lakhani SR et al. Breast cancer stem cells: treatment resistance and therapeutic opportunities. Carcinogenesis $2011 ; 32: 650-658$.

21. Sutherland CM, Mather FJ, Carter RD, Cerise EJ, Krementz ET. Breast cancer as analyzed by the human tumor stem cell assay. Surgery 1983; 94: 370-375.

22. Polyak K, Weinberg RA. Transitions between epithelial and mesenchymal states: acquisition of malignant and stem cell traits. Nat Rev Cancer 2009; 9: 265-273.

23. Harless WW. Cancer treatments transform residual cancer cell phenotype. Cancer Cell Int 2011; $11: 1$. 
24. Korkaya H, Kim Gl, Davis A, Malik F, Henry NL, Ithimakin S et al. Activation of an IL6 inflammatory loop mediates trastuzumab resistance in HER $2+$ breast cancer by expanding the cancer stem cell population. Mol Cell 2012; 47: 570-584.

25. Landsberg J, Kohlmeyer J, Renn M, Bald T, Rogava M, Cron M et al. Melanomas resist T-cell therapy through inflammation-induced reversible dedifferentiation. Nature 2012; 490 412-416.

26. Santisteban M, Reiman JM, Asiedu MK, Behrens MD, Nassar A, Kalli KR et al Immune-induced epithelial to mesenchymal transition in vivo generates breast cancer stem cells. Cancer Res 2009; 69: 2887-2895.

27. Yu TW, Bai L, Clade D, Hoffmann D, Toelzer S, Trinh KQ et al. The biosynthetic gene cluster of the maytansinoid antitumor agent ansamitocin from Actinosynnema pretiosum. Proc Natl Acad Sci USA 2002; 99: 7968-7973.

28. Lambert JM. Drug-conjugated monoclonal antibodies for the treatment of cancer Curr Opin Pharmacol 2005; 5: 543-549.

29. Wang L, Amphlett G, Blattler WA, Lambert JM, Zhang W. Structural characterization of the maytansinoid-monoclonal antibody immunoconjugate, huN901-DM1, by mass spectrometry. Protein Sci 2005; 14: 2436-2446.

30. Chari RV, Martell BA, Gross JL, Cook SB, Shah SA, Blattler WA et al. Immunoconjugates containing novel maytansinoids: promising anticancer drugs. Cancer Res 1992; 52: 127-131.

31. Erickson HK, Park PU, Widdison WC, Kovtun YV, Garrett LM, Hoffman K et al. Antibody-maytansinoid conjugates are activated in targeted cancer cells by lysosomal degradation and linker-dependent intracellular processing. Cancer Res 2006; 66: 4426-4433.

32. Kovtun YV, Audette CA, Mayo MF, Jones GE, Doherty H, Maloney EK et al. Antibody-maytansinoid conjugates designed to bypass multidrug resistance. Cancer Res 2010; 70: 2528-2537.

33. Remillard S, Rebhun LI, Howie GA, Kupchan SM. Antimitotic activity of the potent tumor inhibitor maytansine. Science 1975; 189: 1002-1005.

34. Pegram M, Hsu S, Lewis G, Pietras R, Beryt M, Sliwkowski M et al. Inhibitory effects of combinations of HER-2/neu antibody and chemotherapeutic agents used for treatment of human breast cancers. Oncogene 1999; 18: 2241-2251.

35. Austin CD, De Maziere AM, Pisacane PI, van Dijk SM, Eigenbrot C, Sliwkowski MX et al. Endocytosis and sorting of ErbB2 and the site of action of cancer therapeutics trastuzumab and geldanamycin. Mol Biol Cell 2004; 15: 5268-5282.

36. Krop IE, LoRusso P, Miller KD, Modi S, Yardley D, Rodriguez G et al. A phase II study of trastuzumab emtansine in patients with human epidermal growth factor receptor 2-positive metastatic breast cancer who were previously treated with trastuzumab, lapatinib, an anthracycline, a taxane, and capecitabine. J Clin Oncol 2012; 30: 3234-3241.

37. Subik K, Lee JF, Baxter L, Strzepek T, Costello D, Crowley P et al. The expression patterns of ER, PR, HER2, CK5/6, EGFR, Ki-67 and AR by immunohistochemical analysis in breast cancer cell lines. Breast Cancer (Auckl) 2010; 4: 35-41.

38. Merlin JL, Barberi-Heyob M, Bachmann N. In vitro comparative evaluation of trastuzumab (Herceptin) combined with paclitaxel (Taxol) or docetaxel (Taxotere) in HER2-expressing human breast cancer cell lines. Ann Oncol 2002; 13: 1743-1748.

39. Beier D, Röhrl S, Pillai DR, Schwarz S, Kunz-Schughart LA, Leukel P et al. Temozolomide preferentially depletes cancer stem cells in glioblastoma. Cancer Res 2008; 68: 5706-5715.

40. Brisken C, Duss S. Stem cells and the stem cell niche in the breast: an integrated hormonal and developmental perspective. Stem Cell Rev 2007; 3: 147-156.

41. Diessner J, Bruttel V, Becker K, Pawlik M, Stein R, Häusler S et al. Targeting breast cancer stem cells with HER2-specific antibodies and natural killer cells. Am J Cancer Res 2013; 3 211-220.

42. Park S, Jiang Z, Mortenson ED, Deng L, Radkevich-Brown O, Yang X et al. The therapeutic effect of anti-HER2/neu antibody depends on both innate and adaptive immunity. Cancer Cell 2010; 18: 160-170.

43. Maeda M, Johnson KR, Wheelock MJ. Cadherin switching: essential for behavioral but not morphological changes during an epithelium-to-mesenchyme transition. J Cell Sci 2005 118(Pt 5): 873-887.
44. Piek E, Moustakas A, Kurisaki A, Heldin CH, ten Dijke P. TGF-(beta) type I receptor/ALK-5 and Smad proteins mediate epithelial to mesenchymal transdifferentiation in NMuMG breast epithelial cells. J Cell Sci 1999; 112(Pt 24): 4557-4568.

45. Dhawan $P$, Singh AB, Deane NG, No Y, Shiou SR, Schmidt $C$ et al. Claudin-1 regulates cellular transformation and metastatic behavior in colon cancer. J Clin Invest 2005; 115: 1765-1776.

46. Choi AM, Ryter SW, Levine B. Autophagy in human health and disease. N Engl J Med 2013; 368: 651-662.

47. Espina V, Mariani BD, Gallagher RI, Tran K, Banks S, Wiedemann J et al. Malignant precursor cells pre-exist in human breast DCIS and require autophagy for survival. PloS One 2010; 5: e10240.

48. Gong C, Bauvy C, Tonelli G, Yue W, Delomenie C, Nicolas V et al. Beclin 1 and autophagy are required for the tumorigenicity of breast cancer stem-like/progenitor cells. Oncogene 2012; 32: 22261-22272.

49. Cufi S, Vazquez-Martin A, Oliveras-Ferraros C, Martin-Castillo B, Vellon L, Menendez JA. Autophagy positively regulates the $\operatorname{CD} 44(+) \operatorname{CD} 24(-/ / 0 w)$ breast cancer stem-like phenotype. Cell Cycle 2011; 10: 3871-3885.

50. Wu YT, Tan HL, Shui G, Bauvy C, Huang Q, Wenk MR et al. Dual role of 3-methyladenine in modulation of autophagy via different temporal patterns of inhibition on class I and III phosphoinositide 3-kinase. J Biol Chem 2010; 285: 10850-10861.

51. Kimura T, Takabatake Y, Takahashi A, Isaka Y. Chloroquine in cancer therapy: a double-edged sword of autophagy. Cancer Res 2013; 73: 3-7.

52. Hamacher-Brady A, Stein HA, Turschner S, Toegel I, Mora R, Jennewein N et al. Artesunate activates mitochondrial apoptosis in breast cancer cells via iron-catalyzed Iysosomal reactive oxygen species production. J Biol Chem 2011; 286: 6587-6601.

53. Chen S, Li X, Feng J, Chang Y, Wang Z, Wen A. Autophagy facilitates the Lapatinib resistance of HER2 positive breast cancer cells. Med Hypotheses 2011; 77: 206-208.

54. Girish S, Gupta M, Wang B, Lu D, Krop IE, Vogel CL et al. Clinical pharmacology of trastuzumab emtansine (T-DM1): an antibody-drug conjugate in development for the treatment of HER2-positive cancer. Cancer Chemother Pharmacol 2012; 69: $1229-1240$.

55. Vazquez-Martin A, Lopez-Bonetc E, Cufi S, Oliveras-Ferraros C, Del Barco S, Martin-Castillo $B$ et al. Repositioning chloroquine and metformin to eliminate cancer stem cell traits in pre-malignant lesions. Drug Resist Updat 2011; 14: 212-223.

56. Li Z, Rich JN. Hypoxia and hypoxia inducible factors in cancer stem cell maintenance. Curr Top Microbiol Immunol 2010; 345: 21-30

57. Madeo F, Tavernarakis N, Kroemer G. Can autophagy promote longevity? Nat Cell Bio 2010; 12: 842-846.

58. Mortensen M, Soilleux EJ, Djordjevic G, Tripp R, Lutteropp M, Sadighi-Akha E et al. The autophagy protein Atg7 is essential for hematopoietic stem cell maintenance. J Exp Med 2011; 208: 455-467.

59. Amaravadi RK, Lippincott-Schwartz J, Yin XM, Weiss WA, Takebe N, Timmer W et al. Principles and current strategies for targeting autophagy for cancer treatment. Clin Cancer Res 2011; 17: 654-666.

60. Verma S, Miles D, Gianni L, Krop IE, Welslau M, Baselga J et al. Trastuzumab emtansine for HER2-positive advanced breast cancer. N Engl J Med 2012; 367: 1783-1791.

(1) (2)(2) Cell Death and Disease is an open-access journal By licensed under a Creative Commons Attribution-NonCommercialShareAlike 3.0 Unported License. To view a copy of this license, visit http://creativecommons.org/licenses/by-nc-sa/3.0/ 